Eur. J. Clin. Chem. Clin. Biochem.

Vol. 30, 1992, pp. $761-765$

(C) 1992 Walter de Gruyter \& Co.

Berlin $\cdot$ New York

\title{
Concentrations of Purine Nucleotides and Purine and Pyrimidine Bases in Cerebrospinal Fluid of Neurologically Healthy Children
}

\author{
By M. Castro-Gago ${ }^{1}, F$. Camiña ${ }^{2}, S$. Lojo $^{2}, S$. Rodriguez-Segade ${ }^{2}$ and A. Rodríguez-Núñez ${ }^{1}$ \\ 1 Departamento de Pediatría \\ 2 Laboratorio Central \\ Hospital General de Galicia, Clínico Universitario, Santiago de Compostela, Spain
}

(Received February 21/June 24, 1992)

Summary: The concentrations of the nucleotides AMP and IMP, the nucleosides adenosine, guanosine and inosine, the purine bases adenine, guanine, hypoxanthine and xanthine, urate, and the pyrimidine bases cytosine, thymine and uracil were determined by high performance liquid chromatography in the cerebrospinal fluid of 63 children aged between 1 month and 13 years who showed no sign of neurological disease. The results are compared with those of other authors, and used to establish reference ranges for the above metabolites in the cerebrospinal fluid of children.

\section{Introduction}

Determination of the concentrations of certain ATP metabolites in cerebrospinal fluid (CSF) has proved to be diagnostically useful in a number of neurological disorders involving neuronal hypoxia and possible cerebral lesions $(1-5)$. Among these metabolites, hypoxanthine and xanthine are recognized markers of neuronal hypoxia $(3,4,6)$, while adenosine has been mentioned as an important modulator of neuron function and cerebral blood flow (7-9). These circumstances make it desirable to establish reference ranges for each of these substances, but for obvious ethical reasons this cannot be done by taking samples of CSF from normal children, which is no doubt why the literature in this area is scant and based on very few subjects $(1,3,5,10-12)$; although Gerrits et al. (12) reported reference ranges for children and adolescents aged 3 days to 18 years, their sample included no children between the ages of 12 and 36 months.

To establish reference ranges for children, we have determined the concentrations of AMP, IMP, inosine, adenosine, guanosine, adenine, guanine, hypoxanthine, xanthine, urate, cytosine, thymine and uracil in cerebrospinal fluid by high performance liquid chromatography (HPLC).

\section{Materials and Methods}

The initial sample consisted of children admitted to the Casualty Service with febrile processes or signs requiring lumbar puncture for investigation of the possibility of meningitis or other neurological pathologies; in general, the paediatricians attending them were unaware of other purposes to which the CSF samples were to be put. Children who in the following days developed further signs or symptoms of neurological disease were excluded from the final sample of 63 ( 40 boys and 23 girls aged between 1 month and 13 years), whose final diagnoses are listed in table 1.

The CSF samples were sent immediately to the Central Laboratory, where a $0.5 \mathrm{ml}$ subsample was stored at $-20^{\circ} \mathrm{C}$ pending chromatographic analysis and the remainder $(1-2 \mathrm{ml})$ was used for conventional determination of proteins and cells. All samples with macro- or microscopic signs of contamination by blood were discarded.

The high performance liquid chromatograph consisted of a Beckman 126 double pump with a high-pressure dynamic mixer, a Merck-Hitachi 655A-40 automatic sample injector and a Beckman 168 visible-ultraviolet diode spectrophotometer, all under the control of a computer running Beckman "System Gold" software. Solvents were degassed in a Bransonic ultrasound bath

Chromatography (3) was performed on a Beckman Ultrasphere ODS reverse-phase column, using a gradient of HPLC grade methanol in $20 \mathrm{mmol} / \mathrm{l}$ analysis grade monopotassium phosphate buffer, $\mathrm{pH}$ 6.2; the solvents were filtrered through 0.45 $\mu \mathrm{m}$ pores. The methanol volume fraction was increased from 0.01 to 0.25 over 16 minutes, returning to its initial value in 2 minutes; the flow rate was $1 \mathrm{ml} / \mathrm{min}$. Samples $(50 \mu \mathrm{l})$ were 
Tab. 1. Diagnoses of the patients studied.

\begin{tabular}{lll}
\hline Diagnosis & $\begin{array}{l}\text { No. of } \\
\text { cases }\end{array}$ & $\%$ \\
\hline Viral infection & 24 & 37.5 \\
Tonsillitis & 14 & 21.8 \\
Pneumonia & 8 & 12.5 \\
Otitis & 7 & 10.9 \\
Urinary infection & 2 & 3.1 \\
Bacteriaemia & 2 & 3.1 \\
No pathology & 1 & 1.5 \\
Others (sinusitis, rash, & 6 & 9.4 \\
$\quad$ salmonellosis, varicella, & & \\
$\quad$ arthritis, cephalea) & & \\
\hline
\end{tabular}

injected every 25 minutes; after every 15 successive injections, standards of the substances being determined were run to check calibration drift and the integrity of the column. Absorbance was monitored at 250 and $280 \mathrm{~nm}$.

\section{Substances were identified by}

1) comparison of their retention times with those of pure standards;

2) their absorption spectra in the range $190-320 \mathrm{~nm}$; and

3) comparison of the chromatograms recorded before and after treatment with uricase, adenosine deaminase or myokinase (the peaks eliminated correspond to urate, adenosine and AMP respectively).

Proteins were determined in Technicon RA-1000 by the common turbidimetric procedure, using trichloroacetic and sulphosalicylic acids.

\section{Statistical analysis}

Descriptive statistics are given as mean \pm standard deviation for normally distributed variables and as median (range) for non-normally distributed variables. The 5th and 95th percentiles were calculated for each variable. To investigate the correlation between possibly related variables, least-squares linear regression analysis was performed (for normally distributed variables).

\section{Results}

The patients' ages ranged from 1 month to 160 months (over 13 years), with a median of 36 months
Tab. 2. Clinical and conventional analytical data.

\begin{tabular}{|c|c|c|c|c|}
\hline & Mean & $\begin{array}{l}\text { Stan- } \\
\text { dard } \\
\text { devia- } \\
\text { tion }\end{array}$ & Median & Range \\
\hline $\begin{array}{l}\text { Age (months) } \\
\text { Temperature }\left({ }^{\circ} \mathrm{C}\right)\end{array}$ & $\begin{array}{l}- \\
-\end{array}$ & $\begin{array}{l}- \\
-\end{array}$ & $\begin{array}{l}36 \\
38.5\end{array}$ & $\begin{array}{c}1-160 \\
36.9-40\end{array}$ \\
\hline $\begin{array}{l}\text { Cells }\left(10^{3} / \mathrm{l}\right) \\
\text { Proteins }(\mathrm{g} / \mathrm{l})\end{array}$ & $\overline{0.21}$ & $\overline{0.06}$ & $\begin{array}{l}2 \\
0.20\end{array}$ & $\begin{array}{l}1-12 \\
0.06-0.36\end{array}$ \\
\hline
\end{tabular}

(tab. 2). Fifteen patients were aged under 12 months, 10 between 12 and 24 months, 5 between 24 and 36 months, 6 between 36 and 48 months, 7 between 48 and 60 months, and the remaining 20 patients over 60 months. Data for patient temperature, cell count and protein concentration in cerebrospinal fluid, and leukocyte count in peripheral blood are listed in table 2. There were no significant differences in temperature between different age groups or diagnosis groups.

Table 3 lists the observed concentrations of nucleotides, nucleosides, purine bases and urate in the patients' cerebrospinal fluid. There was no significant correlation between AMP, IMP, inosine, guanosine, adenosine, adenine, guanine, hypoxanthine or urate concentrations and age, axillary temperature, cell count, protein concentration or peripheral leukocyte count, nor any significant association with particular diagnoses. CSF xanthine exhibited the following significant negative correlation with age: Xanthine $(\mu \mathrm{mol} / \mathrm{l})=3.01-0.012 \times$ Age (months $)(\mathrm{p}<0.001$, $\mathrm{r}=-0.46)$. The number of cases with concentrations below the detection limit of the HPLC method employed was one $(1.58 \%)$ for AMP, $7(11.1 \%)$ for adenosine, $12(19.04 \%)$ for guanosine and adenine, and $9(14.3 \%)$ for guanine.

Table 4 summarizes the data for pyrimidine bases in CSF. None of these bases was significantly correlated with age, axillary temperature, cell count, protein

Tab. 3. Concentrations of nucleotides, nucleosides, purine bases and urate in CSF ( $\mu \mathrm{mol} / \mathrm{l})$.

\begin{tabular}{llllll}
\hline & Mean & $\mathrm{SD}$ & Median & Range & $\mathrm{P}_{5}-\mathrm{P}_{95}$ \\
\hline AMP & 1.69 & 0.76 & 1.60 & $0.00-4.32$ & $0.76-2.93$ \\
IMP & - & - & 3.78 & $0.51-12.06$ & $1.03-8.86$ \\
Inosine & 0.64 & 0.35 & 0.61 & $0.12-1.57$ & $0.19-1.24$ \\
Adenosine & - & - & 0.15 & $0.00-9.20$ & $0.00-8.30$ \\
Guanosine & - & - & 0.13 & $0.00-0.57$ & $0.03-0.36$ \\
Adenine & - & - & 0.19 & $0.06-2.40$ & $0.06-1.19$ \\
Guanine & - & 0.50 & $0.00-15.71$ & $0.00-12.04$ \\
Hypoxanthine & 3.92 & 1.58 & 3.54 & $1.44-8.66$ & $1.75-6.84$ \\
Xanthine & 2.40 & 1.10 & 2.27 & $0.66-6.06$ & $1.00-4.64$ \\
Urate & 10.12 & 5.01 & 9.02 & $2.42-22.23$ & $2.94-18.83$ \\
\hline
\end{tabular}


Tab. 4. Concentrations of pyrimidine bases in CSF ( $\mu \mathrm{mol} / \mathrm{l})$.

\begin{tabular}{llll}
\hline & Median & Range & \multicolumn{1}{l}{$\mathrm{P}_{5}-\mathrm{P}_{95}$} \\
\hline Cytosine & 0.75 & $0-10.33$ & $0.00-6.24$ \\
Thymine & 0.28 & $0-2.95$ & $0.00-2.24$ \\
Uracil & 0.58 & $0.14-4.09$ & $0.14-1.30$ \\
\hline
\end{tabular}

concentration or peripheral leukocyte count, nor significantly associated with any particular diagnoses. The number of patients with concentrations below the detection limit of the HPLC method employed was $5(7.9 \%)$ for cytosine and $16(25.4 \%)$ for thymine.

\section{Discussion}

The determination of reference intervals for the metabolites studied in this work was necessary because published research in this area has been scant and incomplete $(3,10,12)$. In fact, we are only aware of one study of a sizeable group of children, and although the patients' ranged from newborns to 18year-olds there were no patients between 1 and 3 years old (12). Notwithstanding this difference, our results are in general similar to those of Gerrits et al. (12) and to those reported for adults $(10,11)$.

\section{AMP}

We know of no reported reference interval for AMP in the CSF of children. In this study, we found concentrations of $1.69 \pm 0.76 \mu \mathrm{mol} / \mathrm{l}$, with $\mathrm{P}_{95}=2.93$ $\mu \mathrm{mol} / 1$.

\section{IMP}

Published data for IMP in the CSF of children is also lacking. The concentrations we found in this work varied widely from 0.51 to $12.06 \mu \mathrm{mol} / \mathrm{l}$, with a median of $3.78 \mu \mathrm{mol} / 1 ; \mathrm{P}_{95}=8.86 \mu \mathrm{mol} / \mathrm{l}$.

\section{Inosine}

The range we observed $(0.64 \pm 0.35 \mu \mathrm{mol} / \mathrm{l})$ is in keeping with those reported by others $(3,10,12)$; in our study $\mathrm{P}_{95}=1.24 \mu \mathrm{mol} / \mathrm{l}$.

\section{Adenosine}

Adenosine concentrations were also very variable, ranging from 0 to $9.20 \mu \mathrm{mol} / 1$, with a median of 0.15 $\mu \mathrm{mol} / \mathrm{l}$ and $\mathrm{P}_{95}$ of $8.30 \mu \mathrm{mol} / 1.11 .1 \%$ of the patients had undetectable adenosine, a finding in keeping with previous reports (12) of the difficulty of detecting adenosine in CSF. Most of our patients had low CSF adenosine concentrations, but a few had concentrations considerably greater than any reported previously for patients with no signs of neurological disease; it seems possible that these exceptionally high concentrations may have been related to febrile processes, since adenosine has been reported to have a vasoregulatory role $(7,16,17)$.

\section{Guanosine}

CSF guanosine concentrations ranged from 0 to 0.57 $\mu \mathrm{mol} / \mathrm{l}$, with a median of $0.13 \mu \mathrm{mol} / 1$ and a $\mathrm{P}_{95}$ of $0.36 \mu \mathrm{mol} / 1$. In a large proportion of patients $(19 \%)$, guanosine was not detectable. Our results are compatible with those of the only previous study of which we are aware (12). CSF guanosine in children with no neurological pathology is thus very low or undetectable.

\section{Adenine}

CSF adenine concentrations ranged between 0.06 and $2.40 \mu \mathrm{mol} / 1$, with a median of $0.19 \mu \mathrm{mol} / 1$ and a $P_{95}$ of $1.19 \mu \mathrm{mol} / 1$. In $19.04 \%$ of the patients adenine was not detectable. These results also agree with those of Gerrits et al. (12). CSF adenine in children with no neurological pathology is thus very low or undetectable.

\section{Guanine}

CSF guanine concentrations varied widely from 0 to $15.71 \mu \mathrm{mol} / \mathrm{l}$, with a median of $0.50 \mu \mathrm{mol} / \mathrm{l}$ and a $\mathrm{P}_{95}$ of $12.04 \mu \mathrm{mol} / 1$. In $14.3 \%$ of the patients, guanine was undetectable. Thus, like adenine, guanine is very low or undetectable except in a small minority of patients with much higher concentration, whose aetiology we do not know. We know of no previous study of guanine in the CSF of children.

\section{Hypoxanthine}

The observed hypoxanthine concentrations were 3.92 $\pm 1.58 \mu \mathrm{mol} / 1$, with $\mathrm{P}_{95}=6.84 \mu \mathrm{mol} / \mathrm{l}$. Previously reported CSF hypoxanthine concentrations are similar to ours (3) or rather lower $(10-12)$ (tab. 5).

\section{Xanthine}

The observed CSF xanthine concentrations were 2.40 $\pm 1.10 \mu \mathrm{mol} / 1$, with $\mathrm{P}_{95}=4.64 \mu \mathrm{mol} / 1$. Xanthine concentration was correlated negatively with age. The concentrations reported by other authors $(3,10-12$, 18) are in general similar to those observed in this 
study, although some are greater (tab. 5). Gerrits et al. (12), found no correlation between age and CSF xanthine concentration.

\section{Urate}

We found CSF urate concentrations of $10.12 \pm 5.01$ $\mu \mathrm{mol} / 1$, with $\mathrm{P}_{95}=18.83 \mu \mathrm{mol} / 1$. The results reported by others $(11,12)$ are in general compatible with ours, although in some studies involving few patients $(3$, 10) higher concentrations were observed.

\section{Cytosine}

CSF cytosine concentrations ranged widely from 0 to $10.33 \mu \mathrm{mol} / 1$, with a median of $0.75 \mu \mathrm{mol} / 1$ and a $\mathrm{P}_{95}$ of $6.24 \mu \mathrm{mol} / 1$. We know of no other study of cytosine in the CSF of children.

\section{Thymine}

In a large proportion of the patients $(25.4 \%)$, thymine was undetectable. The observed range was $0-2.95$ $\mu \mathrm{mol} / \mathrm{l}$, with a median of $0.28 \mu \mathrm{mol} / 1$ and a $\mathrm{P}_{95}$ of $2.24 \mu \mathrm{mol} / 1$. Gerrits et al. (12) found no values greater than $1 \mu \mathrm{mol} / 1$.

\section{Uracil}

CSF uracil concentrations ranged between 0.14 and $4.09 \mu \mathrm{mol} / \mathrm{l}$, with a median of $0.58 \mu \mathrm{mol} / 1$ and a $\mathrm{P}_{95}$ of $1.30 \mu \mathrm{mol} / 1$. The values reported previously (12) are similar to ours.

\section{References}

1. Manzke, H. \& Staemmler, W. (1981) Oxypurine concentrations in the CSF in children with different diseases of the nervous system. Neuropediatrics 12, 209-214.

2. Meberg, A. \& Saugstad, O. D. (1978) Hypoxanthine in cerebrospinal fluid in children. Scand. J. Clin. Lab. Invest. $38,437-440$

3. Harkness, R. A. \& Lund, R. J. (1983) CSF concentrations of hypoxanthine, xanthine, uridine and inosine: high concentrations of the ATP metabolite hypoxanthine after hypoxia. J. Clin. Pathol. 36, $1-8$.

4. Levin, S. D., Brown, J. K. \& Harkness, R. A. (1984) Cerebrospinal fluid hypoxanthine and xanthine concentrations as indicators of metabolic damage due to raises of intracranial pressure in hydrocephalic children. J. Neurol. Neurosurg. Psychiatr. 47, 730-733.

5. Castro-Gago, M., Lojo, S., Del Río, R., Rodríguez, A., Novo, I. \& Rodríguez-Segade, S. (1986) The concentrations of xanthine and hypoxanthine in cerebrospinal fluid as therapeutic guides in hydrocephalus. Child's Nerv. Syst. 2, $109-111$.
Tab. 5. Concentrations of oxypurines found in CSF in this study and others $(\mu \mathrm{mol} / \mathrm{l})$, mean $\pm \mathrm{SD}$

\begin{tabular}{llll}
\hline & $\mathrm{N}$ & Hypoxanthine & Xanthine \\
\hline $\begin{array}{l}\text { Gerrits et al. (12) } \\
\quad(<12 \text { months) }\end{array}$ & 14 & $2.38 \pm 0.89$ & $2.08 \pm 1.06$ \\
$\quad(3-18$ years) & 64 & $2.47 \pm 0.71$ & $1.79 \pm 0.62$ \\
$\quad$ Harkness et al. (3) & 10 & $3.60 \pm 0.90$ & $5.0 \pm 2.0$ \\
$\begin{array}{l}\text { Eells } \text { et al. (10) } \\
\quad \text { (adults) }\end{array}$ & 10 & $2.5 \pm 1.12$ & $2.3 \pm 0.45$ \\
$\begin{array}{l}\text { Hällgren } \text { et al. (11) } \\
\quad(\text { adults) }\end{array}$ & 26 & $2.6 \pm 0.5$ & $1.7 \pm 0.4$ \\
$\begin{array}{l}\text { Livingston } \text { et al. (18) } \\
\text { Our study }\end{array}$ & 19 & $3.6 \pm 1.15$ & $3.1 \pm 0.9$ \\
\hline & 63 & $3.92 \pm 1.58$ & $2.40 \pm 1.10$ \\
\hline
\end{tabular}

\section{Conclusion}

We believe that further studies of purine and pyrimidine metabolites in CSF should be carried out with larger groups of patients to determine reference ranges of greater statistical reliability. We nevertheless consider that the ranges reported here, which agree with those found with the same analytical method by other authors in similar patient groups, will be useful for comparison with values found in children with neurological pathologies.

6. Saugstad, O. D. (1988) Hypoxanthine as an indicator of hypoxia: its role in health and disease through free radical production. Pediatr. Res. 23, 143-150.

7. Craig, L. \& Delivoria-Papadopoulos, M. (1990) Controlling mechanisms in the cerebral circulation of the newborn. In Neonatal seizures (Wasterlain, C. G. \& Vert, P., eds.) pp. 129-141, Raven Press Ltd. New York.

8. Winn, H. R., Rubio, R. \& Berne, R. M. (1981) The role of adenosine in the regulation of cerebral blood flow. J. Cerebr. Blood Flow Metab. 1, 239-244.

9. Marangos, P. J., Daval, J. L., Weiss, S. R. B. \& Post, R. M. (1990) Carbamazepine and brain adenosine receptors. In: Neonatal seizures (Wasterlain, C. G. \& Vert, P., eds.) pp. $201-208$, Raven Press Ltd. New York.

10. Eells, J. T. \& Spector, R. (1983) Purine and pyrimidine base and nucleoside concentrations in human cerebrospinal fluid and plasma. Neurochem. Res. 8, 1451-1457.

11. Hällgren, R., Niklasson, F., Terent, A., Akerblom, A. \& Widerlöv, E. (1983) Oxypurines in cerebrospinal fluid as indices of disturbed brain metabolism. A clinical study on ischemic brain diseases. Stroke 14, 382-388. 
12. Gerrits, G. P., Haagen, A., De Abreu, R., Monnens, L., Gabreëls, F., Trijbels, F., Theeuvens, A. \& van Baal, J. (1988) Reference values for nucleosides and nucleobases in cerebrspinal fluid of children. Clin. Chem. 37, 1439-1442.

13. DeWitt, D. F., Jochim, K. E. \& Behrendt, D. M. (1983) Nucleotide degradation and functional impairment during cardioplegia: Amelioration by inosine. Circulation 67, $171-178$

14. Fox, I. H. (1981) Metabolic basis for disorders of purine nucleotide degradation. Metabolism 30, 616-634.

15. Palella, T. D., Fox, I. H. (1989) Hyperuricemia and gout. In: The metabolic basis of inherited disease (Scriver, C. R., Beaudet, A. L. \& Sly, W. S., eds.) pp. 965-1006, McGrawHill Co. New York.
16. Berne, R. M. (1986) Adenosine: an important physiological regulator. News Physiol. Sci. 1, 163-167.

17. Laudignon, N., Beharry, K., Rex, R. \& Aranda, J. V. (1990) Effect of adenosine on total and regional cerebral blood flow of the newborn piglet. J. Cereb. Blood Flow Metab. $10,392-398$.

18. Livingston, J. H., Brown, J. K., Harkness, R. A. \& McCreanor, G. M. (1989) Cerebrospinal fluid nucleotide metabolites following short febrile convulsions. Dev. Med. Child Neurol. 31, 161-167.
Manuel Castro-Gago
Departamento de Pediatría
Hospital General de Galicia
E-15705 Santiago de Compostela
Spain 
